\title{
側方運動の運動論的分類
}

\author{
長谷川成男真柳 昭 紘 \\ 中野雅徳* 新井泉
}

\section{Mathematical Classification of Lateral Movement}

\section{Shigeo Hasegawa, Akihiro Mayanagi, Masanori Nakano* and Izumi Arai}

\section{I. 緒 言}

下頡運動を表現するには全運動軸を利用するのが最も 合理的であると発表1) されて以来すでに久しいが，この 軸上の側方運動が実測されたのは極く最近のことであ る2). 著者の 1 人である中野3) は側方運動時の㐘牙の Guide の解析を目的として全運動軸上の側方運動を 31 名の被験者について測定, 記録している.

著者ら山ははまた方において咬合器の選択，さらには 咬合面形態といつた值接の対象を臨床に置いた下顎運動 の解析を行つて，側方運動を 4 つの patternに分類する ことの妥当性を示している. ここではこの全運動軸上で の側方運動記録に対してこの方向からの解析を加えてみ る.

\section{II. 解析方法}

\section{1. 資料}

中野3) が被験者 31 名について写真法にて全運動軸上で 測定, 記録した側方運動を資料とする. しかし，中野 ${ }^{3)}$ の歯牙の Guide の在り方に関する解析結果から正常と は見なし難かつた 3 名は除外し，28名，56 例を本解析 の対象とする.なお, 各被験者間の結果に関する比較を 行うために, 平衡側顆頭の移動距離が $4 \mathrm{~mm}$ となる点 を基準側方咬合位としたが, 17 例では記録されている移

東京医科画科大学歯学部第 2 歯科補緅学教室（指導：田端 恒雄教授)

The Second Department of Prosthodontics, School of Dentistry, Tokyo Medical and Dental University (Director : Prof. Tsuneo Tabata)

*長野県厚生農業協同組合連合会, リハビリテーションセン タ一鹿教湯病院歯科

昭和 53 年 2 月 27 日受付
動距離が $4 \mathrm{~mm}$ に達していないので,これらは記しを 符し，別に扱うこととする.

本資料の顆頭中心点での運動方向, 運動量は表 1 およ び図 $1 ， 2$ に示す通りである. なお，図表中作業側顆路 角 (十) とあるのは水平面投影については後方, 前頭面 投影については上方を示す.

\section{2. 解 析 法}

28 名, 56 例の側方運動に対して顆頭間軸一致度 $(\mathrm{H})^{5,6)}$, 彎曲度 $(\mathrm{D})^{7,8)}$ および側方運動の Pattern ${ }^{4)}$ に関する解析 を行う.

1) 顆頭間軸一致度 (H)

側方運動は顆頭間軸の滑走と軸自体の回転で表現で き, 顆路型咬合器も同様の機構をとつているので, 側方 運動の咬合器上での再現性は側方咬合位における生体と 咬合器との顆頭間軸の一致度 $(\mathrm{H})$ で代表させ得る.

調節性咬合器は平衡側顆路を理論的には常に再現でき る.したがつて, 顆頭間軸一致度 $(\mathrm{H})$ は側方咬合位での 生体と咬合器の作業側顆頭点間の実距離となる.この顆 頭間軸一致度 $(\mathrm{H})$ は半調節性咬合器で顆頭間距離が多く $110 \mathrm{~mm}$ に固定されているので, ここでは $\mathrm{H}_{110}$ として, 顆頭間距離可変半調節性咬合器では顆頭間距離を変える $(\Delta \mathrm{L})$ ことによつて $\mathrm{H}$ の最小值を求め得るので, ここで は Hmin として, また全調節性咬合器では $\Delta \mathrm{L}$ に加え て頂角 $60^{\circ}$ の四角錐の調節範囲（現在の多くの咬合器で の調節範用）を作業側顆路に対してもつので，ここでは Hf. として表わす. なお, Hf. は Hmin 点での顆頭間 軸に対する作業側顆路の実角 $\left(\theta \cdot \mathrm{Hmin}\right.$. ) が $30.0^{\circ}$ 以下 の場合には当然 $0.00 \mathrm{~mm}$ となり, 完全再現を意味する ことになる.

2）需曲度 (D)

咬頭嵌合位と側方咬合位とを結ぶ直線に対する側方運 
表 1 側方運動時の顆頭中心点におうける顆路の方向および運動最

（*印は平衡測顆頭点の移動距離が $4 \mathrm{~mm}$ 末満の例）

\begin{tabular}{|c|c|c|c|c|c|c|c|}
\hline & \multirow{2}{*}{$\begin{array}{l}\text { 例 } \\
f_{2 k}^{\prime \prime}\end{array}$} & \multicolumn{3}{|c|}{ 作 少 仳 顆 路 } & \multicolumn{3}{|c|}{ 非 鮒 側 顆 路 } \\
\hline & & 水半绪投影出侁 & 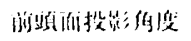 & 移怔距雖 ( $\mathrm{mm}$ ) & 水平面投影偛度 & 矢状面投影角度 & 移動距離 $(\mathrm{mm})$ \\
\hline $\begin{array}{l}\text { 出現柁柬 } \\
\text { 平均値 }\end{array}$ & 39 & $\begin{array}{c}60.8^{\circ}-\left(1119.7^{\circ}\right. \\
1.6^{\circ}\end{array}$ & $\begin{array}{c}111.8^{\circ}-(-) 76.5^{\circ} \\
(-) 6.2^{\circ}\end{array}$ & $\begin{array}{c}1.48-0.16 \\
0.76\end{array}$ & $\begin{array}{c}27.9^{\circ}-0.7^{\circ} \\
11.1^{\circ}\end{array}$ & $\begin{array}{c}54.6^{\circ} \sim 18.8^{\circ} \\
37.2^{\circ}\end{array}$ & $\begin{array}{l}4.0 \\
4.0\end{array}$ \\
\hline $\begin{array}{l}\text { 出現筂四 } \\
\text { 平均値 }\end{array}$ & $17^{*}$ & $\begin{array}{c}91.9^{\circ}-(-) 87.4^{\circ} \\
20.2^{\circ}\end{array}$ & $\begin{array}{c}92.8^{\circ}-\left(168.2^{\circ}\right. \\
4.1^{\circ}\end{array}$ & $\begin{array}{c}1.12-0.30 \\
0.62\end{array}$ & $\begin{array}{c}31.2^{\circ}-1.0^{\circ} \\
8.26^{\circ}\end{array}$ & $\begin{array}{c}46.6^{\circ} \sim 22.5^{\circ} \\
34.3^{\circ}\end{array}$ & $\begin{array}{c}3.83 \sim 1.98 \\
3.31\end{array}$ \\
\hline
\end{tabular}

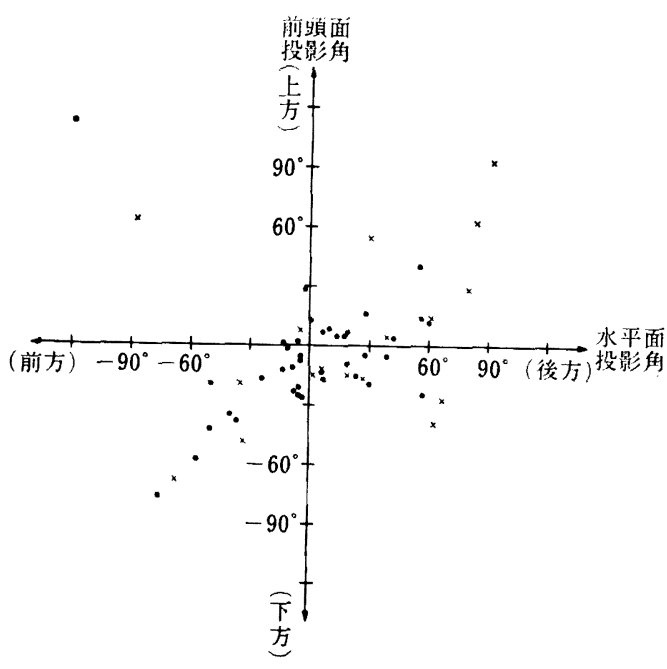

図 1 顆頭中心点の作業侧顆路角（×印は平衡側顆頭点の 移動距離が $4 \mathrm{~mm}$ 米滿の例)

動経路上の数点, 各顎位からの実距離の最大値をもつて 空間的繙曲度 (D) とする.

顆路の繁曲は歯牙路の彎曲に対して影響を及ぼしてい るが，作業側のそれは運動距離が小さいために（表 1) 大きな影響をもたない，しかし，平衡側顆路の繁曲，こ

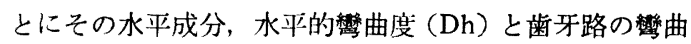
との間には密接な関倸がある ${ }^{81}$.

3）側方運動の分類

側方運動は顆路と顆頭間軸自体の回転で表現できるの で, 側方運動にとつては顆路が最も重要な要素である97. そしてこの顆路は運動方向と経路とで示すのが普通であ る. 運動方向は, 平衡側顆路では出現範囲も狭く, 調節 性咬合器を対象とすれば必ず再現できるので, ここで問 題となるのは作業側の運動方向, すなわち第 1) 項に述 べた顆頭間軸一致度 $(\mathrm{H})$ ということになる。

一方，経路は彎曲度 (D) で代表させれば，作業側のそ

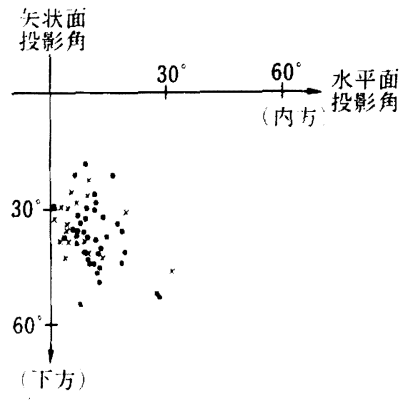

図 2 顆頭中心点の平衡側顆路角（×印は 平衡側顆頭点の移動距離が $4 \mathrm{~mm}$ 胀満の例)

れは運動距離共々小さく、また咬合面部に対しても大き な影響を示さないので，ここでは第2）項に述べた平衡 側の彎曲度 (D) がより大きな問題となる。したがつて, 側方運動は顆頭間軸一致度 $(\mathrm{H})$ と答曲度 $(\mathrm{D})$ とで特徵つ 汁られれ，それをH，Dの大小によつて4型の pattern に分類することはきわめて合理的なことといえる.ま た, ここに咬合器での下䪽運動の近似再現といった概 念 ${ }^{10)}$ 導入すれば，この分類は補緅物作製に当つての咬 合器選択の基準ともなり得る.

\section{III. 結果および考察}

\section{1. 顆頭間軸一致度 $(H)$ および鹪曲度 $(\mathrm{D})$}

被験者 28 名について記録した側方運動を資料として 顆頭間軸一致度拉よび綡曲度を求めた結果は表 2 として 示した. この結果を第 1 小臼歯部での切端咬合位を対象 とした野村4)の 14 例に対する結果ならびに切歯点 $5 \mathrm{~mm}$ 移動(側方咬合位を対象とした真柳6) の 16 例に対する結 果と比較表示したのが表 3 である.ここで野村は平均 的顆頭点を, 真柳はレントゲン写真上で定めた顆頭中心 点を結ぶ線を顆頭間軸としているが，今回のそれは描記 
表 2 顆頭閒軸一致度および彎曲度

\begin{tabular}{|c|c|c|c|c|c|c|c|c|c|}
\hline 被 & 䄼 & 者 & $\mathrm{H}_{110}(\mathrm{~mm})$ & $\mathrm{H} \min (\mathrm{mm})$ & Hf $\quad(\mathrm{mm})$ & $\theta \cdot \mathrm{H} \min \left({ }^{\circ}\right)$ & \lrcorner $\mathrm{L} \quad(\mathrm{mm})$ & D $\quad(\mathrm{mm})$ & $\mathrm{Dh} \quad(\mathrm{mm}$ \\
\hline & \multirow{2}{*}{1} & $\mathrm{R}$ & 0.13 & 0.07 & & 8.9 & -3.22 & 0.12 & 0.08 \\
\hline & & $\mathrm{L}$ & 0.55 & 0.00 & & 1.5 & 20.83 & 0.03 & 0.01 \\
\hline & \multirow{2}{*}{2} & $\mathrm{R}$ & 0.35 & 0.16 & & 18.8 & 9.99 & 0.06 & 0.03 \\
\hline * & & $L$ & 0.17 & 0.08 & & 9.5 & 4.84 & 0.18 & 0.05 \\
\hline \multirow[t]{2}{*}{$*$} & \multirow{2}{*}{3} & $\mathrm{R}$ & 0.25 & 0.25 & & & & 0.26 & 0.26 \\
\hline & & $\mathrm{L}$ & 0.20 & 0.18 & & 16.3 & $-\quad 2.79$ & 0.16 & 0.16 \\
\hline \multirow{2}{*}{\multicolumn{2}{|c|}{4}} & $\mathbf{R}$ & 0.09 & 0.04 & & 4.1 & -2.25 & 0.12 & 0.07 \\
\hline & & $\mathrm{L}$ & 0.29 & 0.05 & & 3.6 & 9.00 & 0.32 & 0.32 \\
\hline \multirow{2}{*}{\multicolumn{2}{|c|}{5}} & $\mathrm{R}$ & 0.12 & 0.12 & & 13.3 & -0.22 & 0.14 & 0.09 \\
\hline & & $\mathrm{L}$ & 0.52 & 0.21 & & 13.2 & 14.11 & 0.15 & 0.15 \\
\hline \multirow{2}{*}{\multicolumn{2}{|c|}{6}} & $\mathrm{R}$ & 0.43 & 0.00 & & 0.0 & 14.24 & 0.24 & 0.15 \\
\hline & & $\mathrm{L}$ & 0.33 & 0.21 & & 10.3 & 10.64 & 0.37 & 0.31 \\
\hline \multirow{2}{*}{\multicolumn{2}{|c|}{7}} & $\mathrm{R}$ & 0.12 & 0.12 & & 31.1 & 0.27 & 0.20 & 0.02 \\
\hline & & $\mathrm{L}$ & 0.20 & 0.18 & & 20.4 & 2.85 & 0.12 & 0.11 \\
\hline * & \multirow{2}{*}{8} & $\mathrm{R}$ & 0.16 & 0.11 & & 11.9 & 2.47 & 0.06 & 0.03 \\
\hline$*$ & & $\mathrm{~L}$ & 0.37 & 0.14 & 0.03 & 39.1 & -9.57 & 0.29 & 0.07 \\
\hline * & \multirow{2}{*}{9} & $\mathrm{R}$ & 0.27 & 0.09 & 0.04 & 48.2 & 10.99 & 0.11 & 0.06 \\
\hline * & & $\mathrm{L}$ & 0.36 & 0.03 & & 3.9 & 14.54 & 0.06 & 0.02 \\
\hline \multirow{2}{*}{\multicolumn{2}{|c|}{ * 10}} & $\mathrm{R}$ & 0.60 & 0.06 & 0.06 & 79.5 & -15.46 & 0.12 & 0.08 \\
\hline & & $\mathrm{L}$ & 0.16 & 0.13 & 0.12 & 85.4 & $\cdots 2.59$ & 0.14 & 0.06 \\
\hline \multirow{2}{*}{\multicolumn{2}{|c|}{11}} & $\mathrm{R}$ & 0.24 & 0.17 & & 26.8 & -4.57 & 0.19 & 0.16 \\
\hline & & $\mathrm{L}$ & 0.25 & 0.23 & & 17.9 & 2.16 & 0.15 & 0.14 \\
\hline \multirow{2}{*}{\multicolumn{2}{|c|}{ * 12}} & $\mathrm{R}$ & 0.24 & 0.20 & & 24.3 & -4.18 & 0.12 & 0.10 \\
\hline & & $\mathrm{L}$ & 0.52 & 0.34 & 0.08 & 38.5 & -12.05 & 0.08 & 0.04 \\
\hline \multirow{2}{*}{\multicolumn{2}{|c|}{13}} & $\mathrm{R}$ & 0.89 & 0.18 & 0.09 & 54.6 & 29.85 & 0.12 & 0.04 \\
\hline & & $\mathrm{L}$ & 0.33 & 0.14 & & 25.8 & 8.53 & 0.23 & 0.12 \\
\hline \multirow{2}{*}{\multicolumn{2}{|c|}{14}} & $\mathrm{R}$ & 0.11 & 0.05 & & 6.6 & -2.62 & 0.21 & 0.20 \\
\hline & & $\mathrm{L}$ & 0.08 & 0.07 & & 11.6 & $\cdots 0.41$ & 0.23 & 0.22 \\
\hline \multirow{2}{*}{\multicolumn{2}{|c|}{15}} & $\mathbf{R}$ & 0.28 & 0.28 & & 26.2 & -1.85 & 0.08 & 0.04 \\
\hline & & $\mathrm{L}$ & 0.12 & 0.02 & & 2.9 & 3.48 & 0.12 & 0.11 \\
\hline \multirow{2}{*}{\multicolumn{2}{|c|}{16}} & $\mathbf{R}$ & 0.30 & 0.26 & 0.02 & 32.6 & $\cdots 4.07$ & 0.23 & 0.01 \\
\hline & & $\mathrm{L}$ & 0.20 & 0.19 & & 23.0 & -3.60 & 0.12 & 0.06 \\
\hline \multirow{2}{*}{\multicolumn{2}{|c|}{ * 17}} & $\mathrm{R}$ & 0.65 & 0.32 & 0.23 & 69.3 & -19.44 & 0.13 & 0.13 \\
\hline & & $\mathrm{L}$ & 0.51 & 0.20 & & 24.1 & -12.16 & 0.42 & 0.19 \\
\hline \multirow{2}{*}{\multicolumn{2}{|c|}{18}} & $\mathrm{R}$ & 0.62 & 0.08 & & 19.0 & 21.18 & 0.07 & 0.05 \\
\hline & & L & 0.04 & 0.03 & & 5.6 & 0.30 & 0.14 & 0.03 \\
\hline \multirow{2}{*}{\multicolumn{2}{|c|}{19}} & $\mathbf{R}$ & 0.16 & 0.14 & & 16.3 & 1.92 & 0.42 & 0.42 \\
\hline & & $\mathrm{L}$ & 0.28 & 0.00 & & 0.0 & -7.24 & 0.18 & 0.18 \\
\hline
\end{tabular}




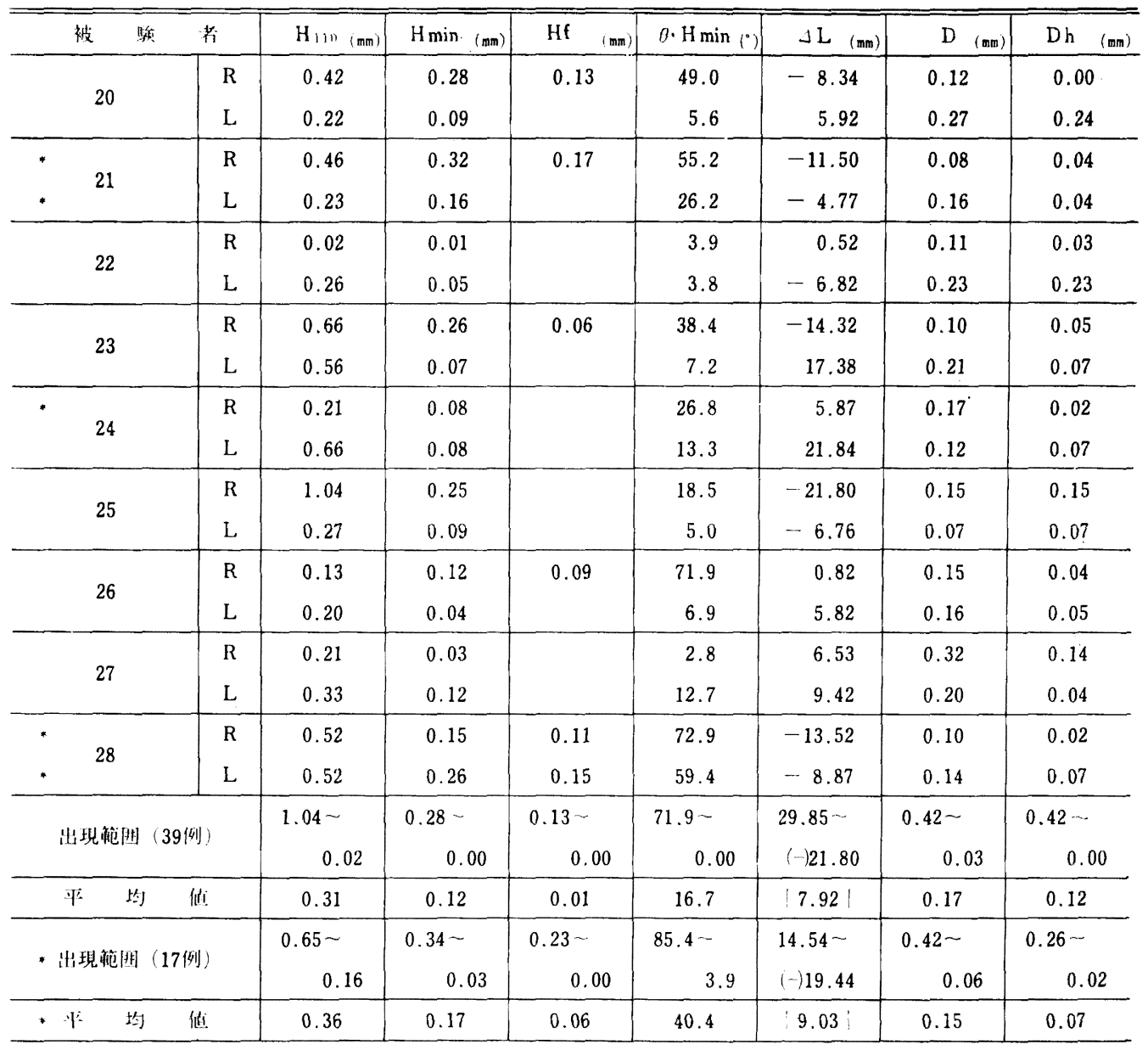

表 3 顆頭間軸一致度および維曲度:

\begin{tabular}{|c|c|c|c|c|c|c|c|}
\hline & & $\mathrm{H}_{110}(\mathrm{~mm})$ & $\mathrm{H} \min \quad(\mathrm{mm})$ & $\mathrm{Hf} \quad(\mathrm{mm})$ & \lrcorner $\mathrm{L} \quad(\mathrm{mm})$ & D $\quad(\mathrm{mm})$ & $\mathrm{Dh}$ \\
\hline 野 村 & 出現舵敶 & $0.17 \sim 0.98$ & $0.12 \sim 0.80$ & & $14.71-(-) 25.54$ & $0.06 \sim 0.46$ & \\
\hline 14 (例) & 平均㑲 & 0.41 & 0.33 & & 8.06 & 0.26 & \\
\hline 空 柳 & 出現笵珊 & $0.08 \sim 0.52$ & $0.02 \sim 0.40$ & $0.00 \sim 0.14$ & $11.5 \sim(-) 5.4$ & $0.06 \sim 0.25$ & $0.02 \sim 0.24$ \\
\hline 16例 & 平均值 & 0.28 & 0.17 & 0.02 & $|4.8|$ & 0.17 & 0.09 \\
\hline 著者的 & 出現蹜洲 & $0.02 \sim 1.04$ & $0.00 \sim 0.28$ & $0.00 \sim 0.13$ & $29.85 \sim(-) 21.80$ & $0.03 \sim 0.42$ & $0.00 \sim 0.42$ \\
\hline 39例 & 平均佔 & 0.31 & 0.12 & 0.01 & $|7.92|$ & 0.17 & 0.12 \\
\hline
\end{tabular}

法11)によつて求めた全運動軸を顆頭間軸としているので 野村, 真柳らとは基準軸を異にするという見方もある が, 顆頭間軸一致度 $(\mathrm{H})$ ならびに彎曲度 $(\mathrm{D})$ をその出現 箱囲，平均值などから総合的に考虑すると，野村の結果
が一部で僅かに大きい值を示すところもあるが，いずれ に拄いても大差なき結果を示しているものとも言えよ 5 .

本資料ではそれぞれの顆頭における全運動軸点と平均 
表 4 刢方運動の分類、各型の出現頻度

（小は $0.2 \mathrm{~mm}$ 以下）

\begin{tabular}{|c|c|c|c|c|c|c|c|}
\hline & & & $\underset{(\mathrm{H})}{\mathrm{H} \text { min }}$ & D & $\begin{array}{l}\text { 野村 } \\
\text { (14例) }\end{array}$ & $\begin{array}{l}\text { 真柳 } \\
\text { (16例) }\end{array}$ & $\begin{array}{l}\text { 著者埌 } \\
(39 \text { 剔) }\end{array}$ \\
\hline 第 & I & 型 & 小 & 小 & $2(0)$ & $10(6)$ & 21(11) \\
\hline 第 & II & 型 & 小 & 大 & 6 & 0 & 10 \\
\hline 第 & III & 型 & 大 & 小 & 4 & 3 & 6 \\
\hline 第 & IV & 型! & 大 & 大 & 2 & 3 & 2 \\
\hline
\end{tabular}

的顆頭点との位置関係を求めていないが, 河野 ${ }^{1)}$ の研究 によれば 10 例で $1.2 \sim 6.5 \mathrm{~mm}$, 平均 $2.9 \mathrm{~mm}$, 特殊な 1 例を除いては平均 $2.5 \mathrm{~mm}$ と比較的近接した雨者間 での位㯰差を示している. 全運動軸点は，河野1)の論文 に詳述をみるが，必ずしも 1 点として定まつてくるもの ではなく，ほぼ等価と考えても良い点がある範囲内で面 積として分布するとのことである.さらに，本資料では 描記法に拠つていることから全運動軸点となる条件を少 しゅるめて河野1) のこれに関わる分布図 (文献1) の図 9 参照）をみると顆路の厚さが $1 \mathrm{~mm}$ 以下となる顆頭点 の分布範囲は顆頭中心点を含むような状況となつてい る. 以上のことから, 顆頭間軸一致度, 彎曲度といつた 問題に関する限り, 全運動軸点, 顆頭中心点, 平均的顆 頭点といつた形態的にみるこの程度の位置差は，通常大 きな意味をもつて現われてはこないのではなかろうかと 考えている.

\section{2. 側方運動の分類}

顆路の運動方向の 1 つの指標である顆頭間軸一致度 (H) と顆路の経路の 1 つの指標である㙰曲度 (D) とによ る側方運動の分類が咬合器の選択法と密接な関係にある ことについては既に報告した ${ }^{4)}$.この分類法は，臼歯部 運動経路延いては臼歯部咬合面形態とも深いつながりを もち，相当に重要な意味をもつので，ここでは大小を分 つ基準值を一応 $0.2 \mathrm{~mm}^{10}$ ) としたとき各型の出現頻度 について表示した（表 4 ）.

顆頭間軸一致度の最小值 $\mathrm{Hmin}$, 彎曲度 D ともに小さ い第 I 型に属する側方運動が最も多く21 例で, 全例の $54 \%$ を占めた. この第 I 型に，これと同様にDの小さい 第而型を加えるとほほ70\%となるので，側方運動につ いて顆路の曲を考慮しなければならない症例は $30 \%$ 程度ということになる. Hmin，Dともに大きい第IV型 は 2 例， $5 \%$ と最も少ない側方運動の pattern であつ た. こうした傾向は形態的顆頭点に関して顆頭間軸一致 度，曲度を求めて分類した野村，真柳の結果（表 4)
表 5 全頉補緅を想定した際の側方運動各型の出現頻度

（小は $0.2 \mathrm{~mm}$ 以下）

\begin{tabular}{|c|c|c|c|c|c|c|c|}
\hline & & & $\underset{(\mathrm{H})}{\mathrm{Hmin}}$ & $\mathrm{D}$ & $\begin{array}{l}\text { 野 村 } \\
(7 \text { 例) }\end{array}$ & $\begin{array}{l}\text { 真 柳 } \\
\text { (8 } 8 \text { 列) }\end{array}$ & $\begin{array}{l}\text { 著者） } \\
\left(17 \text { bin刂 }^{\circ}\right.\end{array}$ \\
\hline 第 & I & 型 & 小 & 小 & 0 & $3(1)$ & $4(2)$ \\
\hline 第 & II & 型 & 小 & 火 & 2 & 0 & 6 \\
\hline 第 & III & 型 & 火 & 小 & 2 & 2 & 4 \\
\hline 第 & IV & 型 & 火 & t & 3 & 3 & 3 \\
\hline
\end{tabular}

においても同様にみられた.

また,この分類法に沿つて全䪽補緅物を作製するとの 観点から咬合器を選択しようとすれば, 表 5 のような結 果となる(平衡側顆路が左右側とも $4 \mathrm{~mm}$ 以上移動し た被験者 17 名についての結果). 表 5 において被験者は 全 4 型に均等に存在し, 第 I 型に対応寸る半調節性咬合 器, 顆頭間距離可変半調節性咬合器, 第而型に対応する 值線顆路全調節性咬合器, 第IV型に対応する曲線顆路全 調節性咬合器はそれぞれに有用なことがわかつた. ま た, 第 II 型に対応する曲線顆路半調節性咬合器は現在明 確な形では存在しないが, 最近発表された immediate side shift 機構を具えた各種の半調節性咬合器はある意 味ではこれに近い機能を示す咬合器 ${ }^{21}$ なので,これらの 咬合器には考案される必然性があつたとも言える.

しかし，咬合器の調節という面からは水平面投影彎曲 度 Dh が最も重要とも考えられるので8), 先の側方運動 の分類を立体的檤曲度 Dではなく, Dh で行うと，39例 中新たに 6 例を加えて 33 例が顆路の警曲という面で問 題がなくり，第 I 型は 5 例増加して 26 例となるので, 顆 頭間距離可変半調節性咬合器がもつ実際的意義は相当に 高いものと考えられる。

\section{IV. 総 括}

全運動軸上で記録した側方運動に対して著者らの教室 で確立した 1 つの解析法を適用し，28名 56 例の側方運 動を 4 型に分類して各型の出現頻度を示した。

稿を終るに臨み，種々ご援助下さつた田端教授をはじめと寸 る第 2 芷科補稀学教室の諸先生に深謝致しま寸。

なお，演算には東大大型計算機センターを利用した。

\section{文献}

1）河野正司：下顎の矢状面内運動に対応する顆頭運動の 
研究, 第二報 マルチフラッジュ装謂による矢状面運動 軸の解析, 補緅誌, $12: 350 \sim 380$, 昭43 (1968).

2）長谷川成男，藍稳，河野正司，坂東永一, 真柳昭紘, 野村孝太郎、福島俊士，川口豊造：下影限界運動におけ る全運動軸の立体的測定, 補緅詀，19:434 443, 昭 50 (1975).

3) 中野雅徳：側方滑走運動における顆路上米牙路に関す ろ研究, 補释誌, 19:461 479, 昭51 (1976).

4) 長谷川成男, 真柳昭紘, 野村孝太郎：側方運動の $\mathrm{Pa}$ ttern からみた咬合器の選択法, 補緅誌, $18 ： 122 １ 25$, 昭49 (1974).

5)野村孝太郎：側方咬合位における咬合器の再現性と運 動様式に関する研究, 補緅誌, $15: 239 \sim 266$, 昭 46 (1971).

6）真柳昭紘：作業側顆頭の運動様相と咬合器の再現性に
関する研究，補緅誌，18：126〜133，昭49 (1974).

7）長谷川成男，野村孝太郎，他：咬合器の再現性に成する 検討, -Graphic Tracing 法とCheckbite 法につい て—、補緅誌， $16 ： 138 \sim 143$ ，昭47（1972）。

8）真柳昭紘：側方滑走運動路における淛曲に関する研究, 補緅誌，17：205～213，昭48（1973）。

9）長谷川成男，野村孝太郎，他：側方滑走運動における運 動様式の検討, 補緅誌, $16: 381 \sim 386$, 昭47 (1972).

10）長谷川成男, 塩澤㕕己：咬合器の選び方—咬合調整と 近似再現と側方運動の䛦断一, 日本齿科評論, 416 : $25 \sim 35,417: 25 \sim 33$, 昭52 (1977).

11）河野正司, 福島俊士：全運動軸の描記法による求め方, 補緅誌, $17: 121 \sim 125$, 昭48 (1973).

12）長谷川成男, 新井 泉 : 咬合器の分類, 補緅臨床/別冊 一調節性咬合器—D. 43 54, 昭52 (1977). 